\title{
Production and validation of model iron-tannate dyed textiles for use as historic textile substitutes in stabilisation treatment studies
}

\author{
Helen Wilson ${ }^{1,2^{*}}$, Chris Carr ${ }^{1}$ and Marei Hacke ${ }^{2}$
}

\begin{abstract}
Background: For millennia, iron-tannate dyes have been used to colour ceremonial and domestic objects shades of black, grey, or brown. Surviving iron-tannate dyed objects are part of our cultural heritage but their existence is threatened by the dye itself which can accelerate oxidation and acid hydrolysis of the substrate. This causes many iron-tannate dyed textiles to discolour and decrease in tensile strength and flexibility at a faster rate than equivalent undyed textiles. The current lack of suitable stabilisation treatments means that many historic iron-tannate dyed objects are rapidly crumbling to dust with the knowledge and value they hold being lost forever.

This paper describes the production, characterisation, and validation of model iron-tannate dyed textiles as substitutes for historic iron-tannate dyed textiles in the development of stabilisation treatments. Spectrophotometry, surface $\mathrm{pH}$, tensile testing, SEM-EDX, and XRF have been used to characterise the model textiles.

Results: On application to textiles, the model dyes imparted mid to dark blue-grey colouration, an immediate tensile strength loss of the textiles and an increase in surface acidity. The dyes introduced significant quantities of iron into the textiles which was distributed in the exterior and interior of the cotton, abaca, and silk fibres but only in the exterior of the wool fibres. As seen with historic iron-tannate dyed objects, the dyed cotton, abaca, and silk textiles lost tensile strength faster and more significantly than undyed equivalents during accelerated thermal ageing and all of the dyed model textiles, most notably the cotton, discoloured more than the undyed equivalents on ageing.

Conclusions: The abaca, cotton, and silk model textiles are judged to be suitable for use as substitutes for cultural heritage materials in the testing of stabilisation treatments.
\end{abstract}

\section{Background}

Iron-tannate complexes have been used as inks (iron gall inks) and dyes for thousands of years and are now present in objects of cultural significance worldwide. While iron gall inks have been used predominantly on paper and parchment, iron-tannate dyes have been used to colour a vast array of woven and non-woven materials shades of black, grey, or brown, including proteinaceous materials such as silk (Figure 1), wool, skin, and leather, and cellulosic materials such as cotton, abaca, Phormium tenax (New Zealand flax) (Figure 2), and raffia.

\footnotetext{
* Correspondence: helenlouisewilson@gmail.com
${ }^{1}$ Textiles and Paper, The School of Materials, The University of Manchester,

${ }^{*}$ Textiles and Paper, The School of Materials, The University of Manchester,
'Terrespondence: helenlouisewilson@gmail.com Oxford Road, Manchester M13 9PL, UK

${ }^{2}$ Department of Conservation and Scientific Research, British Museum, Great Russell Street, London WC1B 3DG, UK
}

Iron-tannate dyes are formed through the combination of iron ions (usually iron(II)) and tannic acids (usually hydrolysable) in water. Historically, iron ions were often sourced from iron-rich mud or iron(II) sulphate (vitriol) while tannic acid (condensed, hydrolysable, or a mixture) was sourced from plant material such as bark, leaves, and galls. Hydrolysable tannins from galls for example include gallotannins and ellagitannins which can be hydrolysed to glucose and gallic acid or ellagic acid, respectively [1]. On combination with ferrous ions hydrolysable tannins form blue-black coloured iron(III)-tannate dye complexes; the colour being due to a reversible charge transfer across the $\mathrm{Fe}(\mathrm{III})-\mathrm{O}$ bond in the iron(III)-tannate, or iron(III)-gallate, complex [2]. Condensed tannins (proanthocyanidins) are oligomers or polymers of flavan-3-ol (catechin) monomers [1] which form green-black coloured dye complexes
(C) Chemistry Central

C 2012 Wilson et al.; licensee Chemistry Central Ltd. This is an Open Access article distributed under the terms of the Creative Commons Attribution License (http://creativecommons.org/licenses/by/2.0), which permits unrestricted use, distribution, and reproduction in any medium, provided the original work is properly cited. 


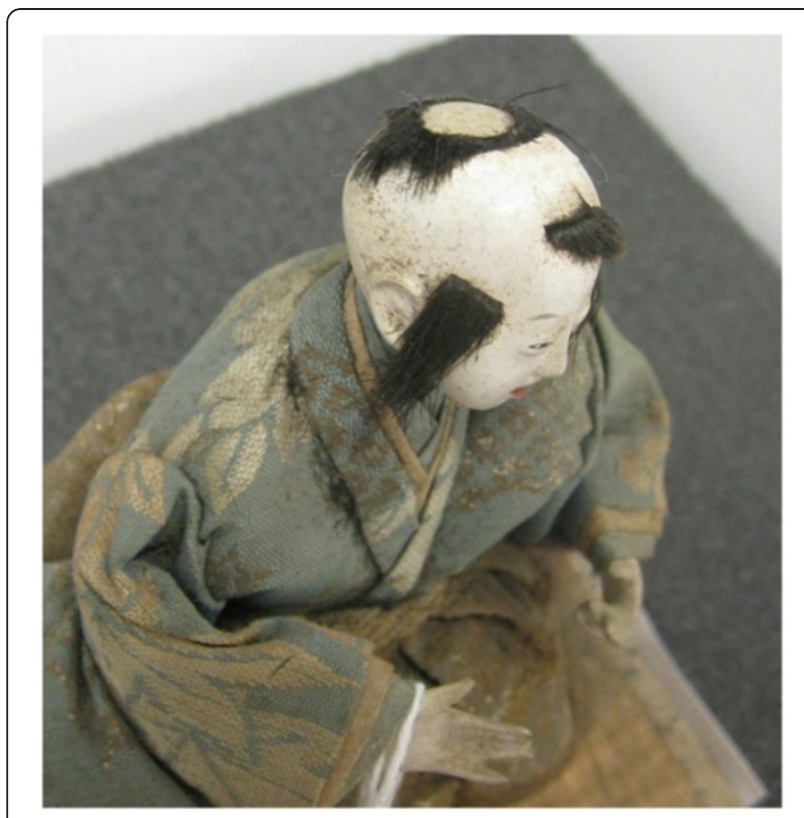

Figure 1 Losses to the iron-tannate dyed hair (silk) on a Japanese ceremonial Hina doll (British Museum, Department of Asia,

AS1981,0808.227). Image (c) The Trustees of the British Museum.
Unfortunately, iron gall inks and iron-tannate dyes pose a significant threat to the lifetime of the materials they colour due to their acidity and metal ion content which can accelerate acid hydrolysis and oxidation (see Additional file 1 for more details). This causes tensile strength loss, embrittlement, and discolouration in the substrate. Consequently, many iron-tannate dyed materials are brown rather than black, fragile, exhibit physical losses, or in some cases have crumbled to dust (Figure 3).

While much research has been undertaken into understanding the degradation processes and development of stabilisation treatments for iron gall ink on paper $[2,8,9]$ significantly less research has been undertaken on the iron-tannate dyed textiles that are the focus of this paper [3,4,10-13], and at present there is no suitable non-aqueous treatment with which to stabilise these objects.

In 2008 an AHRC/EPSRC Science and Heritage Programme collaborative $\mathrm{PhD}$ project was established at the University of Manchester and the British Museum to investigate non-aqueous stabilisation treatments for irontannate dyed organic materials. The use of historic material in these treatment studies was deemed unsuitable

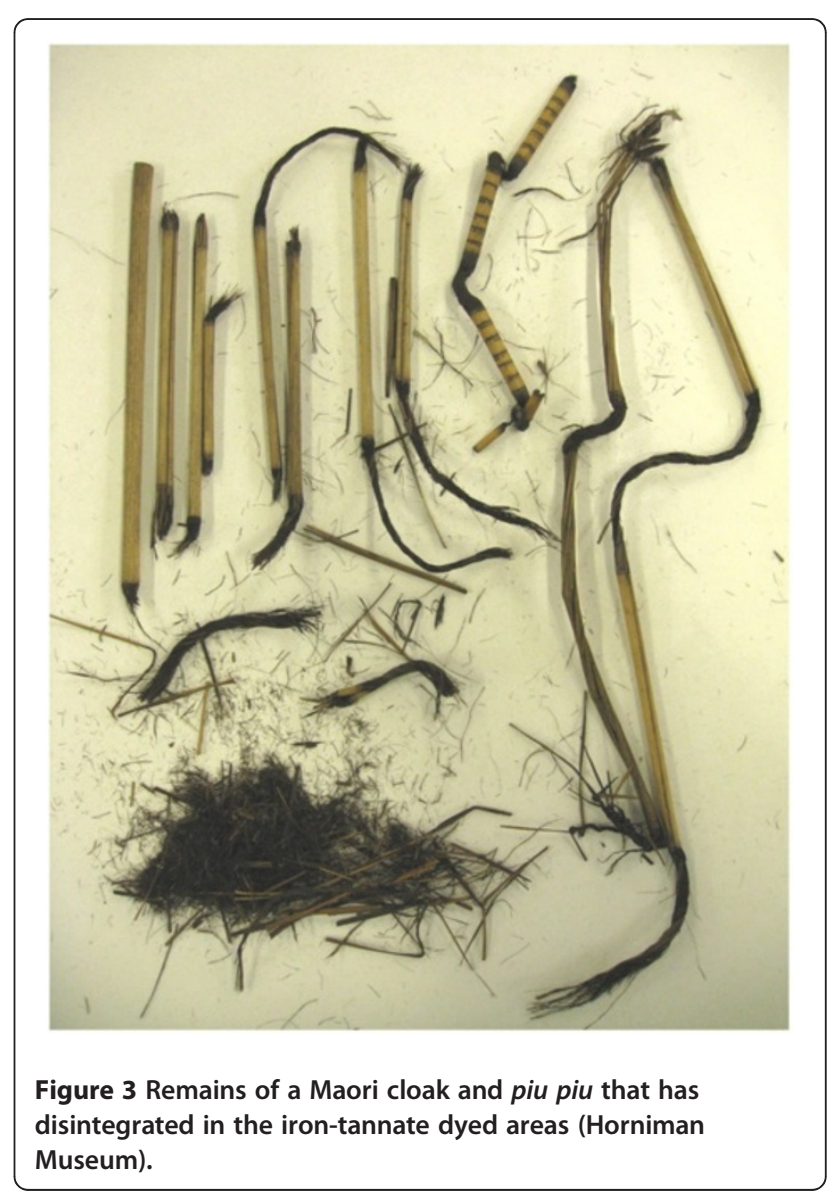

on combination with iron(III) ions [3,4]. The exact shade of black, brown, or grey of iron-tannate dyes varies depending on the method of dyeing used and the types and quality of reagents included [5]. Additionally, the dyes can become browner with age as the dye complex is broken down and coloured degradation products such as brown quinones and iron(III) oxides, and yellow ellagic acid are formed [6,7]. See Additional file 1 for further detail on the colour, acidity, and complex structure of iron-tannate dyes.

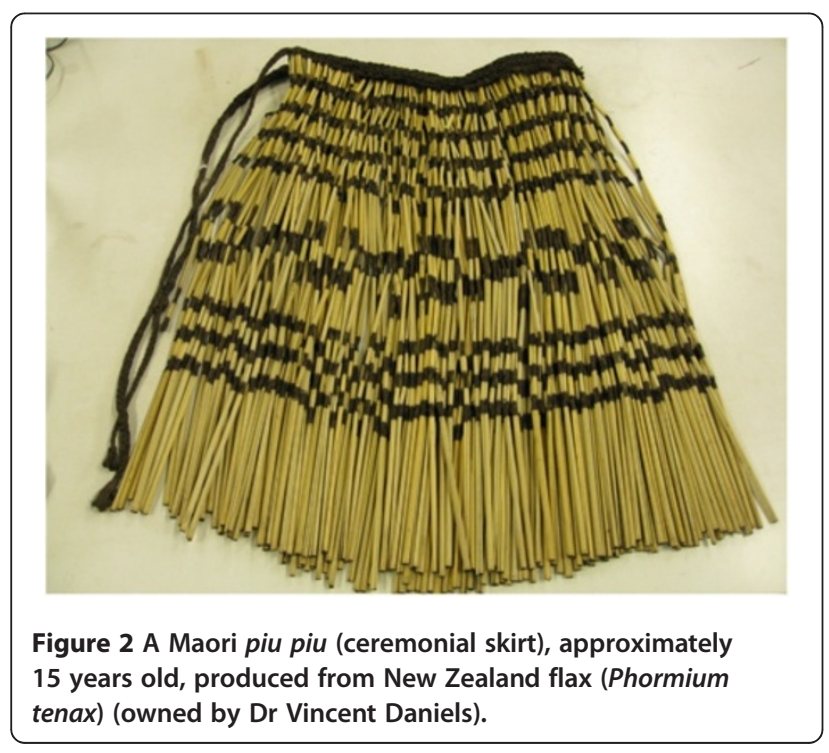


for ethical and practical reasons and necessitated the production and use of substitute iron-tannate dyed textiles that:

- Exhibit relatively uniform iron and colour distribution to ensure that the iron-catalysed degradation of the dyed textiles occurs as uniformly as possible, thus minimising analytical variability in accelerated ageing and stabilisation treatment studies;

- Lose tensile strength and possibly discolour more than undyed equivalent textiles on accelerated ageing, as is seen with naturally aged iron-tannate dyed objects worldwide including in the British Museum's collection $[4,10]$.

In this paper the production of the substitute textiles is described. The validity for the use of the textiles as substitutes for historic iron-tannate dyed material in accelerated ageing and stabilisation treatment studies is assessed through their characterisation before and after accelerated ageing.

\section{Production of substitute textiles}

Small quantities of iron-tannate dyed silk [12], New Zealand flax [3], and raffia [13] yarns/fibre bundles and textiles have been produced in laboratories by several researchers. For this research significantly larger quantities of uniformly dyed woven textiles were needed and so four textiles (cotton, abaca, silk, and wool) and six specifically developed dye formulations (Table 1) were used on industrial equipment at the University of Manchester's dyehouse to produce an unprecedented $80 \mathrm{~m}^{2}$ of substitute textiles. The $\mathrm{pH}$ of the clear and colourless dyebath solutions was tested using $\mathrm{pH}$-Fix 0-14 Fisherbrand $\mathrm{pH}$ indicator strips and found to be typically $\mathrm{pH} 4$ to 6 for both tannic acid solutions and metal ion solutions. More detailed information on the development and dyeing of the substitute textiles is presented in Additional file 2.

\section{Results and discussion}

Characterisation of unaged iron-tannate dyed model textiles Metal ion content and distribution, including uniformity, in irontannate dyed model textiles (XRF and SEM-EDX analysis)

XRF was used to assess the overall metal ion content and uniformity throughout the dyed textiles since an uneven distribution could cause uneven degradation during accelerated ageing.

All iron-tannate dye formulations introduced significant quantities of iron (and copper for the p2 and c2 formulations) into the dyed textiles (Table 2). Dye formulation 3 resulted in the highest levels of iron detected probably due to a greater quantity of tannic acid and gallic acid being present in the aqueous gall powder extract compared to in the mixture of tannic acids used in dye formulations 1 and 2 .

The most uniform metal distributions were achieved with dye formulation 3 (a maximum of $6 \%$ variation from the mean) and the least with dye formulation 1 (a maximum of $25 \%$ variation from the mean). The production method, particularly the efficacy of the postdyeing rinsing may have caused these variations in iron content. High levels of iron were also detected in a range of samples from iron-tannate dyed museum objects.

SEM-EDX of the dyed ( $\mathrm{p} 1$ and $\mathrm{c} 1$ ) and undyed substitute textile cross-sections identified a high variability of iron content in the fibre bundles/yarns, with iron concentration increasing with increasing proximity to the fibre bundle/yarn surface. This variation in the iron content with the location of the fibre within the fibre bundles/yarns will occur throughout the textiles and therefore will not affect the results from tensile testing or colour measurement which will be averaged by analysis of multiple fibres.

Importantly, for the individual fibres of abaca, cotton, and silk, iron was easily detected on the exterior and the interior of each fibre and was most concentrated on the exterior (Figure 4). Iron in the wool fibres was primarily located at the exterior of the fibres (cuticle) with minimal or no iron detected inside the fibres (cortex), Figure 5. This is due to the hydrophobic and highly cross-linked cuticle layer present in only the wool fibres, which restricts diffusion of the water-based dye into the cortex of the wool fibres [14]. The lack of a cuticle layer in the silk explains the greater iron content in the silk than in the simultaneously dyed wool (Table 2). Improved dye diffusion into the wool fibres may be achieved through use of a higher temperature such as the $90-100^{\circ} \mathrm{C}$ usually used for wool dyeing, rather than the $55^{\circ} \mathrm{C}$ used in these dye formulations. In this study, $55^{\circ} \mathrm{C}$ was selected in order to minimise thermal damage to the simultaneously dyed silk.

It is likely that the majority of the metal in the substitute textiles is bound in iron-tannate complexes or directly to the fibres since significant or complete removal of water-soluble unbound ions will have occurred in the post-dyeing rinsing. The iron-tannate dye complexes can be physically bonded to the textile fibres via Van der Waals' forces [15-17] or chemically bonded via the mordant of the dye. In the proteinaceous dye formulations, the metal ions acted as mordants so that fibre/ iron/tannic acid interactions will predominate [18]; in the cellulosic dye formulations tannic acid was the mordant and so fibre/tannic acid/iron interactions will predominate. Iron ions and copper ions can bind to hydroxyl, carbonyl, and carboxyl groups in proteinaceous and cellulosic textiles as well as to amine, amide, and thiol groups present in proteinaceous textiles $[15,16,19]$. Copper ions 
Table 1 Dye formulations used to produce substitute iron-tannate dyed textiles

\begin{tabular}{|c|c|c|c|c|c|c|c|}
\hline Dye code & & Substrate & $\begin{array}{l}\text { Liquor: } \\
\text { Fabric }^{\mathrm{a}}\end{array}$ & Dyebath $A^{b}$ & Dyebath B & Dyebath A+ & $\begin{array}{l}\text { Dyeing } \\
\text { sequence }\end{array}$ \\
\hline \multirow[t]{3}{*}{ Proteinaceous } & p1 & Wool + silk & $200: 3.23$ & $0.02 \mathrm{M} \mathrm{FeSO}_{4} .7 \mathrm{H}_{2} \mathrm{O} 55^{\circ} \mathrm{C}, 1$ hour & $6.5 \mathrm{~g} . \mathrm{L}^{-1} \mathrm{TA} 55^{\circ} \mathrm{C}, 3$ hours & $0.009 \mathrm{M} \mathrm{FeSO}_{4} .7 \mathrm{H}_{2} \mathrm{O} 55^{\circ} \mathrm{C}, 1$ hour & $\mathrm{ABABA+}$ \\
\hline & $\overline{p 2}$ & Wool + silk & $200: 3.23$ & $\begin{array}{l}0.02 \mathrm{M} \mathrm{FeSO}_{4} .7 \mathrm{H}_{2} \mathrm{O}+ \\
0.002 \mathrm{M} \mathrm{CuSO}_{4} .5 \mathrm{H}_{2} \mathrm{O} 55^{\circ} \mathrm{C}, 1 \text { hour }\end{array}$ & $6.5 \mathrm{~g} \cdot \mathrm{L}^{-1} \mathrm{TA} 55^{\circ} \mathrm{C}, 3$ hours & $\begin{array}{l}0.009 \mathrm{M} \mathrm{FeSO}_{4} .7 \mathrm{H}_{2} \mathrm{O}+ \\
0.0009 \mathrm{M} \mathrm{CuSO}_{4} .5 \mathrm{H}_{2} \mathrm{O} 55^{\circ} \mathrm{C}, 1 \text { hour }\end{array}$ & $A B A B A+$ \\
\hline & p3 & Silk & $200: 0.62$ & $0.005 \mathrm{M} \mathrm{FeSO}_{4} .7 \mathrm{H}_{2} \mathrm{O} 55^{\circ} \mathrm{C}, 1$ hour & $3.5{\mathrm{~g} . \mathrm{L}^{-1} \mathrm{G} \times 55^{\circ} \mathrm{C}, 3 \text { hours }}$ & $0.002 \mathrm{M} \mathrm{FeSO}_{4} .7 \mathrm{H}_{2} \mathrm{O} 55^{\circ} \mathrm{C}, 1$ hour & $\mathrm{ABABA+}$ \\
\hline \multirow[t]{3}{*}{ Cellulosic } & $\mathrm{C} 1$ & Cotton + abaca & $60: 2.01$ & $15 \mathrm{g.L}^{-1} \mathrm{TA} 20^{\circ} \mathrm{C}, 2$ hours & $0.04 \mathrm{M} \mathrm{FeSO}_{4} .7 \mathrm{H}_{2} \mathrm{O} 20^{\circ} \mathrm{C}, 2$ hours & - & $A B A B A B$ \\
\hline & $c 2$ & Cotton + abaca & $60: 2.01$ & $15 \mathrm{~g} . \mathrm{L}^{-1} \mathrm{TA} 20^{\circ} \mathrm{C}, 2$ hours & $\begin{array}{l}0.04 \mathrm{M} \mathrm{FeSO}_{4} .7 \mathrm{H}_{2} \mathrm{O}+ \\
\quad 0.005 \mathrm{M} \mathrm{CuSO}_{4} .5 \mathrm{H}_{2} \mathrm{O} 20^{\circ} \mathrm{C}, 2 \text { hours }\end{array}$ & - & $A B A B A B$ \\
\hline & $\mathrm{c3}$ & Cotton & $60: 1.22$ & $16.6 \mathrm{~g}^{-\mathrm{L}^{-1} \mathrm{G} \times 20^{\circ} \mathrm{C}, 2 \text { hours }}$ & $0.024 \mathrm{M} \mathrm{FeSO}_{4} \cdot 7 \mathrm{H}_{2} \mathrm{O} 20^{\circ} \mathrm{C}, 2$ hours & - & $A B A B A B$ \\
\hline
\end{tabular}

a. Ratio in litres of dyebath : total mass of fabric in kilograms.

b. Abbreviations are as follows: TA: 50:50 mixture of non-purified and purified tannic acid extracts from Chinese galls and sumac, respectively; Gx: non-purified gall powder.

c. In $\mathrm{p} 1$, the final quantity of iron $(A+)$ was added directly to the final dyebath $B$ but in $p 2$ and $p 3$, it was applied in a separate dyebath due to substantial and problematic foam formation in $p 1$. Since an unknown

quantity of tannic acid remained in the final dyebath B in $\mathrm{p} 1$ when the iron $(\mathrm{A}+)$ was added, the effective concentration of iron ions available for binding with tannic acid on or within the textile fibres is lower than that in $\mathrm{p} 2$ and $\mathrm{p} 3$. 
Table 2 The uniformity of metal ion and colour distribution in unaged substitute textiles determined using XRF and spectrophotometry, respectively

\begin{tabular}{|c|c|c|c|c|c|}
\hline \multirow[t]{2}{*}{ Sample } & \multicolumn{2}{|c|}{$\mathrm{XRF}^{\mathrm{a}}$ (elemental ratios) } & \multicolumn{3}{|c|}{ Colour measurement } \\
\hline & $\overline{\mathrm{Fe}}$ & $\mathrm{Cu}$ & $\mathrm{L}^{*}$ & $a^{*}$ & $\mathbf{b}^{*}$ \\
\hline Wool undyed (WU) & $12(1)^{b}$ & $5(1)$ & $78.39(0.39)$ & $-1.06(0.04)$ & $6.67(0.24)$ \\
\hline Wool dyed with p1 (Wp1) & $590(60)$ & $11(1)$ & $33.53(1.03)$ & $1.31(0.04)$ & $-1.11(0.12)$ \\
\hline Wool dyed with p2 (Wp2) & $786(68)$ & $333(27)$ & $31.03(0.79)$ & $0.93(0.07)$ & $-1.05(0.18)$ \\
\hline Silk undyed (SU) & $17(2)$ & $4(1)$ & $75.36(0.36)$ & $-0.20(0.02)$ & $0.97(0.12)$ \\
\hline Silk dyed with p1 (Sp1) & $2124(526)$ & $9(5)$ & $20.75(0.37)$ & $1.46(0.03)$ & $-3.90(0.09)$ \\
\hline Silk dyed with p2 (Sp2) & $2413(292)$ & $204(26)$ & $18.76(0.30)$ & $1.61(0.03)$ & $-4.37(0.07)$ \\
\hline Silk dyed with p3 (Sp3) & $2628(145)$ & $11(10)$ & $17.79(0.20)$ & $1.38(0.03)$ & $-4.09(0.07)$ \\
\hline Abaca undyed (AU) & $24(5)$ & $4(3)$ & $74.25(1.66)$ & $1.91(0.41)$ & $13.56(1.09)$ \\
\hline Abaca dyed with c1 (Ac1) & 1459 (338) & $9(2)$ & $21.66(0.75)$ & $0.56(0.05)$ & $-2.22(0.12)$ \\
\hline Abaca dyed with c2 (Ac2) & $1490(190)$ & $371(53)$ & $23.34(0.83)$ & $0.50(0.04)$ & $-2.65(0.17)$ \\
\hline Cotton undyed (CU) & $15(1)$ & $3(1)$ & $84.31(0.51)$ & $-0.26(0.02)$ & $0.67(0.09)$ \\
\hline Cotton dyed with c1 (Cc1) & $683(145)$ & $5(3)$ & $35.7(0.91)$ & $0.70(0.06)$ & $-4.33(0.15)$ \\
\hline Cotton dyed with c2 (Cc2) & $742(41)$ & $83(11)$ & $33.58(0.50)$ & $0.80(0.04)$ & $-4.89(0.12)$ \\
\hline Cotton dyed with c3 (Cc3) & $1115(44)$ & $3(3)$ & $29.61(1.01)$ & $0.57(0.05)$ & $-4.62(0.13)$ \\
\hline Black silk $(1881,0802.158$ or PRN: RRM 10294 $)$ & 2370 & 587 & $N D^{d}$ & ND & ND \\
\hline Black dyed North American skin bag $\left(1937,0617.1^{\complement}\right)$ & 4163 & 44 & ND & ND & ND \\
\hline $\begin{array}{l}\text { Brown braided area of modern piu piu owned } \\
\text { by Dr Vincent Daniels (Figure 2) }\end{array}$ & 1918 & 2 & ND & ND & ND \\
\hline $\begin{array}{l}\text { Black fibres of broken Maori cloak and piu piu } \\
\text { from the Horniman Museum (Figure 3) }\end{array}$ & 5924 & 3 & ND & ND & ND \\
\hline
\end{tabular}

a. Iron and copper content ratios (net elemental peak area: net Compton peak area) multiplied by 1000 .

b. Standard deviations of mean data are in parentheses.

c. British Museum registration number.

d. Not done because the samples were too small or the surface too uneven for analysis.

bind more strongly than iron ions, particularly to thiols [20-22]. Carboxylate anion groups are the major binding sites in wool [20] and silk [23]. The isoelectric points of wool and silk are approximately at $\mathrm{pH} 5.6$ and 2.8, respectively [24], and are the $\mathrm{pH}$ values at which the proteins are electrically neutral, having equal quantities of positive (e.g. $-\mathrm{NH}_{3}^{+}$) and negative (e.g. $-\mathrm{COO}^{-}$) functional groups. Since the $\mathrm{pH}$ of the dyebaths for the model textiles ranged between $\mathrm{pH} 4$ and 6 , it is likely that the silk fibroin will be slightly negatively charged which will attract the metal cations, while the wool will be either slightly positively charged which will repel the metal cations, or will be electrically neutral. In the silk the metal ions can bind by co-ordinate bonds to un-ionised groups such as amines and hydroxyl groups as well as by ionic bonds to negatively charged groups such as carboxylate and sulphonate groups [25-27]. In the wool the metal ions will be repelled by positively charged groups such as protonated amines but can bind to un-ionised groups such as amine groups, and to the ionised carboxyl groups that account for the majority or all of the carboxyl groups present in the wool since the $\mathrm{pH}$ of dye baths are close to the isoelectric point of wool. Wool p2 contains more copper ions than silk p2 because of its greater aspartic acid, glutamic acid [28], and thiol content [15].

The carbonyl, carboxyl, and hydroxyl groups in cellulosic materials can bind to tannic acid (by hydrogen bonding) as well as to metal ions $[15,16]$. Dyed abaca contains more iron and copper than equivalently dyed cotton probably because of the greater presence of noncellulosic components such as lignin and hemicellulose which also contain hydroxyl and carboxyl groups [29,30].

\section{Iron-tannate dyed textile colour and colour uniformity}

The colour of textiles can be described using reflectance spectra such as those in Figure 6, or quantified using co-ordinates of a colour space system such as CIE $\mathrm{L}^{*} \mathrm{a}^{*}$ $\mathrm{b}^{*}$ (Table 2). The co-ordinate values $\mathrm{L}^{*}, \mathrm{a}^{*}$, and $\mathrm{b}^{*}$ correspond to the blackness $\left(L^{*}=0\right)$, whiteness $\left(L^{*}=100\right)$, redness $(+a)$, greenness $(-a)$, yellowness $(+b)$, and blueness (-b), respectively [31]. A uniform colour distribution is needed to minimise error in characterising colour changes associated with ageing and stabilisation treatment studies.

All of the iron-tannate dyes caused similar mid to dark blue/grey colouration of the substitute textiles (Figure 6). The colour is due to a charge transfer in the iron- 

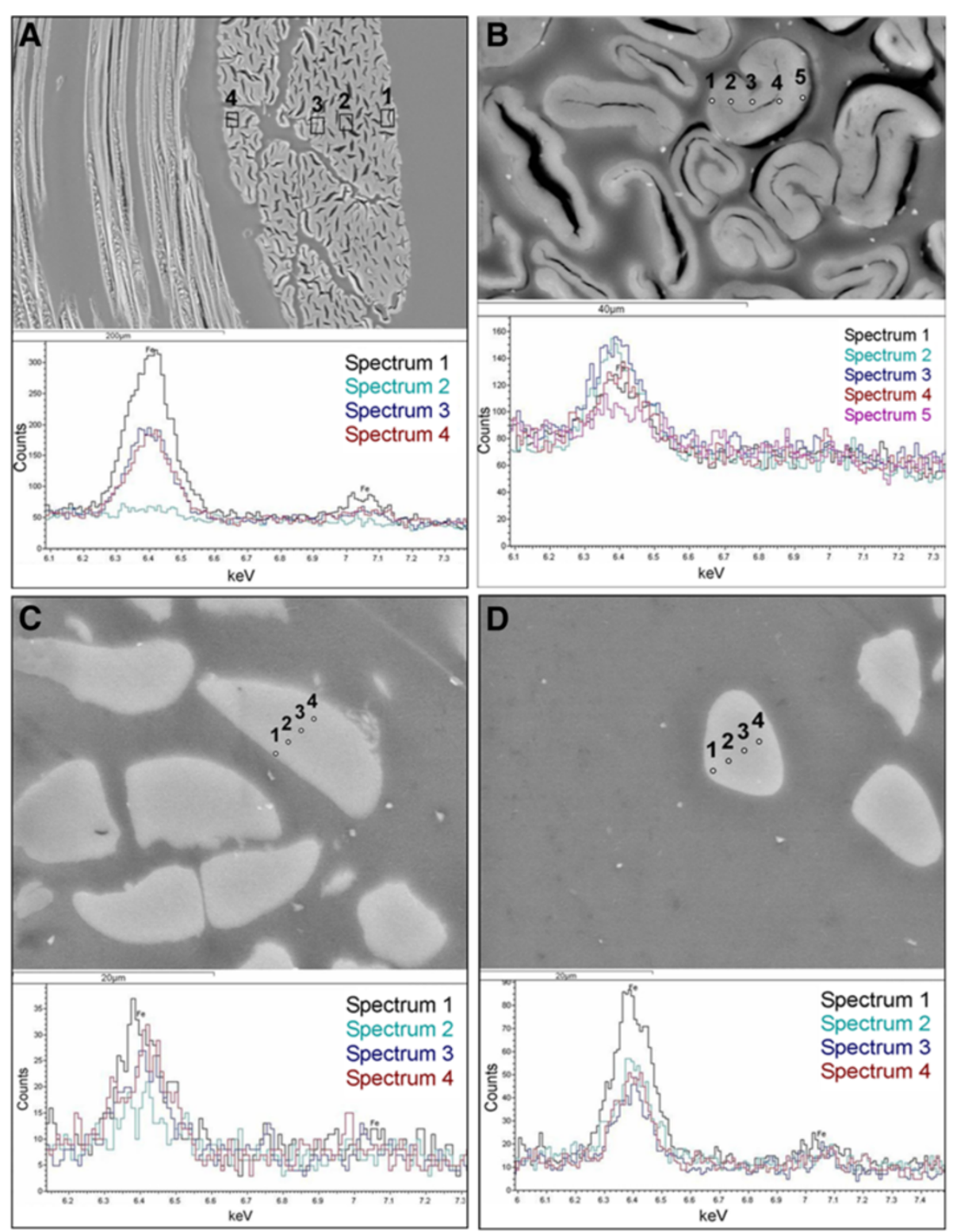

Figure 4 SEM images and EDX spectra of dyed abaca (A), cotton (B), and silk (C and D) fibres in cross-section. The dyed silk fibres in C are from the interior of the yarn while those in $D$ are on the crown of the weave.

tannate dye complex [2] which causes a relatively strong absorption of red light $(600-700 \mathrm{~nm}$ with an absorption maximum at $\mathrm{pH} 4$ of $620 \mathrm{~nm}$ [6]). Comparable reflectance spectra have been reported with laboratory produced iron gall ink [6] and traditionally dyed Phormium tenax (New Zealand flax) [32]. Increasing levels of iron in the textiles (Table 2) correlate well with their $L^{*}, a^{*}$, and $\mathrm{b}^{*}$ values.

Examination of the dyed fabrics indicated that relatively uniform textile colouration was achieved with variations in $L^{*}, a^{*}$, and $b^{*}$ being generally less than $10 \%$ of the mean.

\section{Surface $\mathrm{pH}$ of model textiles}

Iron-tannate dyed textiles are typically acidic, primarily due to the hydroxyl and carboxyl functionalities of the tannic acid (see Additional file 1 for more details). This is demonstrated by the surface $\mathrm{pH}$ of iron-tannate dyed museum objects (Table 3 ) and the aqueous $\mathrm{pH}$ results from the same or similar iron-tannate dyed objects reported in the literature $[10,33]$. Correspondingly, the dyed substitute textiles were found to be acidic, exhibiting surface $\mathrm{pH}$ values between 2.65 and 3.91 which is significantly lower than the surface $\mathrm{pH}$ of the undyed equivalents which ranged between pH 5.36 and 7.46 (Table 3). 


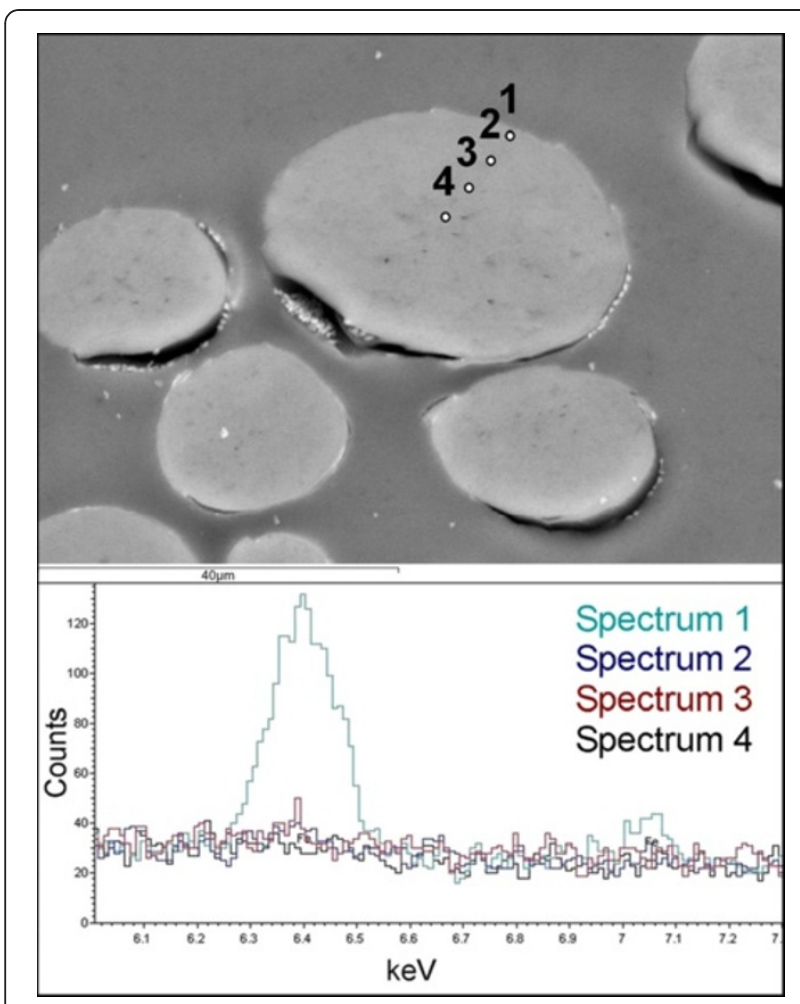

Figure 5 SEM image and EDX spectra of a dyed wool fibre near the crown of the weave.

\section{Changes in substitute textile tensile strength and extensibility due to dye application}

Generally, the application of the dyes caused significant loss of tensile strength (breaking load) and extensibility in the textiles, even before any accelerated ageing had occurred (Table 3). Dyeing of abaca caused the greatest
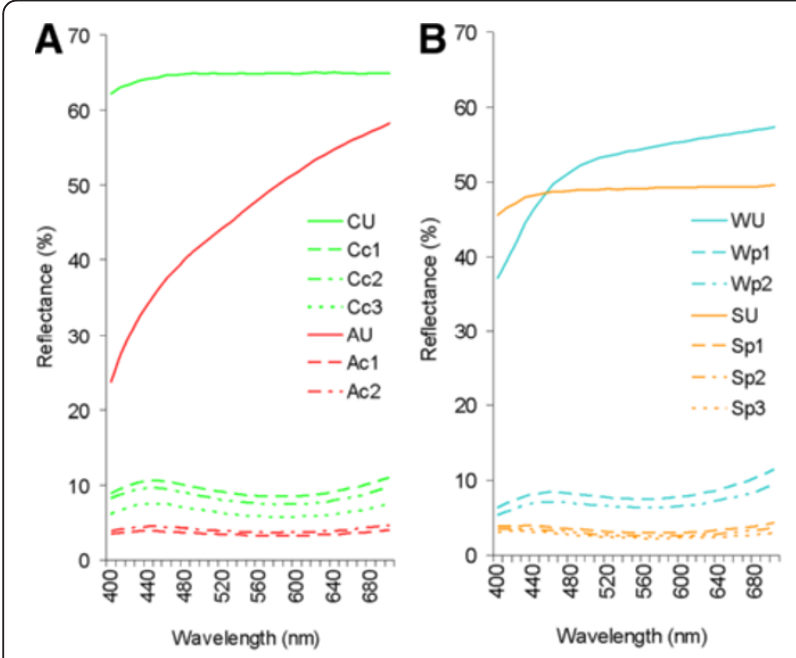

Figure 6 Visible reflectance spectra of the unaged cellulosic (A) and proteinaceous (B) substitute textiles. tensile strength loss of all the substitute textiles, followed by cotton, and finally silk. Wool was not tested since the high tensile strength of the wool led to unacceptable slippage of the sample during testing. The damage could be due to the acidity ( $\mathrm{pH} 4$ to 6 ) and, for the silk, the elevated temperature $\left(55^{\circ} \mathrm{C}\right)$ of the dyebath solutions. Harsh dyeing conditions could be a major factor in the tensile strength loss seen in historic iron-tannate dyed textiles, especially as soluble iron ions and acid can be removed from the textiles during post-dyeing rinsing [34].

\section{Characterisation of model textiles following accelerated ageing (tensile testing and spectrophotometry)}

Despite showing the greatest variation in iron ion distribution (Table 2), the $\mathrm{c} 1$ and $\mathrm{p} 1$ substitute textiles were chosen to be aged as they were dyed with the highest purity and most essential reagents (iron ions and tannic acids) only, thus minimising the influence of impurities.

Little or no change in tensile strength (breaking load) or extensibility was seen in the undyed materials after four weeks of ageing. However, significant loss of tensile strength and extensibility occurred in the dyed abaca and cotton (Ac1 and Cc1) after one week of accelerated ageing and in the dyed silk (Sp1) after two weeks of ageing (Figure 7 and Table 4). The extent of degradation exhibited by the dyed textiles correlates well with their initial surface $\mathrm{pH}$ (Table 3), iron content (Table 2), and the presence of iron in the structurally important internal areas of the dyed fibres, suggesting that the degradation has occurred by acid hydrolysis and metalcatalysed oxidation, similar to that observed in historic iron-tannate dyed textiles [10]. The proportion of degradation occurring by the two mechanisms may be different to those experienced during natural ageing due to the elevated environmental conditions during accelerated ageing, but the essential result of catalysed loss of tensile strength and extensibility of iron-tannate dyed textiles has been determined.

Ac1 lost tensile strength and extensibility faster than $\mathrm{Cc} 1$ and was too fragile for tensile testing after 2 weeks of ageing. This faster rate of degradation is congruent with the greater presence of non-cellulosic components such as hemicellulose $[29,30]$, and the higher iron content (Table 2) in Ac1 than Cc1.

The $L^{*}, a^{*}, b^{*}$ colour coordinates of a sample identify a point in $3 \mathrm{D}$ CIELAB colour space that describes the colour of the sample. The colour difference between two samples, e.g. between the aged and unaged substitute textiles, is described by $\Delta \mathrm{E}_{00}{ }^{*}$ which is the distance in 3D CIELAB colour space between the points that describe the colour of these samples. The CIE2000 colour difference formula that is based on the law of Pythagoras is used to calculate $\Delta \mathrm{E}_{00}{ }^{*}$ [31,35]. Depending on various factors such as surface texture, background, 
Table 3 The surface $\mathrm{pH}$, breaking load, and extension of the unaged substitute textiles and iron-tannate dyed museum objects

\begin{tabular}{|c|c|c|c|}
\hline \multirow[t]{2}{*}{ Sample } & \multirow[t]{2}{*}{ Surface $\mathrm{pH}$} & \multicolumn{2}{|c|}{ Tensile testing } \\
\hline & & Breaking load $(\mathrm{N})$ & Extension (\%) \\
\hline Wool undyed (WU) & $7.46(0.49)^{a}$ & $N D^{b}$ & $N D^{b}$ \\
\hline Wool dyed with p1 (Wp1) & $3.91(0.10)$ & ND & ND \\
\hline Wool dyed with p2 (Wp2) & $3.84(0.11)$ & ND & ND \\
\hline Silk undyed (SU) & $7.24(0.09)$ & $70.2(4.9)$ & $28.2(1.7)$ \\
\hline Silk dyed with p1 (Sp1) & $3.60(0.06)$ & $62.9(4.9)$ & $25.0(2.6)$ \\
\hline Silk dyed with p2 (Sp2) & $3.69(0.09)$ & $56.4(2.5)$ & $22.9(1.7)$ \\
\hline Silk dyed with p3 (Sp3) & $3.57(0.06)$ & $55.3(3.8)$ & $22.6(1.6)$ \\
\hline Abaca undyed (AU) & $5.36(0.18)$ & $239.9(43.1)$ & $3.9(0.5)$ \\
\hline Abaca dyed with c1 (Ac1) & $2.86(0.07)$ & $105.9(18.3)$ & $2.1(0.3)$ \\
\hline Abaca dyed with c2 (Ac2) & $2.67(0.08)$ & $130.1(24.8)$ & $2.5(0.5)$ \\
\hline Cotton undyed (CU) & $6.61(0.11)$ & $73.2(7.7)$ & $10.5(1.1)$ \\
\hline Cotton dyed with $\mathrm{c} 1$ (Cc1) & $2.72(0.06)$ & $68.3(5.3)$ & $6.9(0.7)$ \\
\hline Cotton dyed with c2 (Cc2) & $2.65(0.07)$ & $51.0(4.8)$ & $9.2(1.3)$ \\
\hline Cotton dyed with c3 (Cc3) & $2.48(0.04)$ & $45.7(8.6)$ & $10.2(1.9)$ \\
\hline $\begin{array}{l}\text { Dyed areas of modern piu piu owned } \\
\text { by Dr Vincent Daniels (Figure 2) }\end{array}$ & $3.72(0.28)$ & ND & ND \\
\hline $\begin{array}{l}\text { Black fibres of broken Maori cloak and piu piu } \\
\text { from the Horniman Museum (Figure 3) }\end{array}$ & $2.89(0.19)$ & ND & ND \\
\hline Black cotton Akali Sikh turban $\left(2005,7-27.1^{\circ}\right)$ & 3.39 & ND & ND \\
\hline
\end{tabular}

a. Standard deviations are noted in parentheses when more than one analysis of a sample was taken.

b. Not done due to either slippage of sample in the jaws of the tensile tester (wool samples) or the samples being too small to test (historic samples).

c. British Museum registration number.

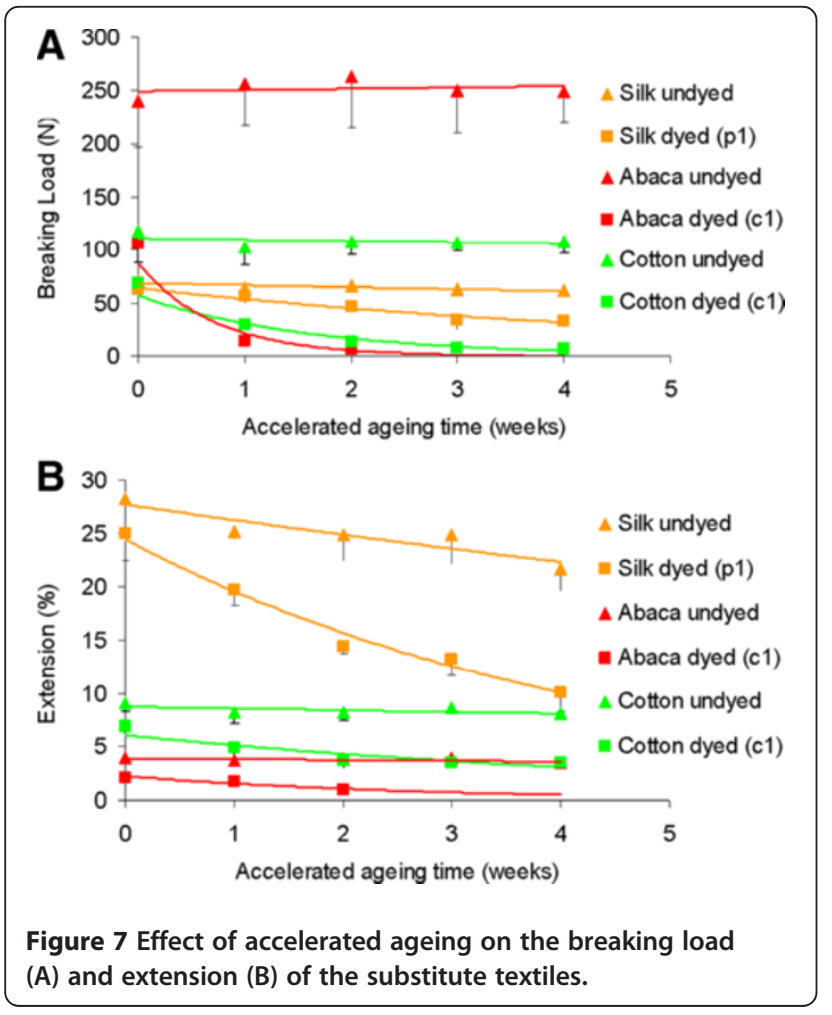

and viewing angle, $50 \%$ of observers can perceive a colour difference between samples of $\Delta \mathrm{E}_{00}{ }^{*}=1$, while the majority can perceive a colour difference of 3 or more [36].

After 4 weeks of accelerated ageing there was little overall change in colour of the undyed textiles $\left(\Delta \mathrm{E}_{00}{ }^{*}<4\right)$ (Figure 8 and Table 4). The dyed textiles (p1 and c1) changed colour more than the simultaneously aged undyed equivalents. The dyed cotton showed significantly greater colour change $\left(\Delta \mathrm{E}_{00}{ }^{*}=13.24\right)$ than the other dyed textiles $\left(\Delta \mathrm{E}_{00}{ }^{*}<6\right)$.

More specifically, a small yellowing $\left(+\Delta \mathrm{b}^{*}\right)$ of the undyed textiles occurred during accelerated ageing which for the cotton, wool, and silk was less than that seen in the dyed equivalents. The dyed textiles (Figure 9 and Table 4) showed an increase in redness $\left(+\Delta \mathrm{a}^{*}\right.$ and a greater reflectance of $600-700 \mathrm{~nm}$ light), particularly for the dyed cotton and abaca, and yellowness $\left(+\Delta \mathrm{b}^{*}\right.$ and a greater reflectance of 560-600 nm light) with age. These results are explained by the breakdown of the blue-black iron-tannate dye complex with thermal ageing as previously described [6,7] (see also Additional file 1), which has been observed with model iron gall inks on paper and traditionally dyed New Zealand flax on ageing [6,32]. The reflectance spectra of the four week accelerated aged dyed cotton and abaca correlate well with the reflectance spectra of the cellulosic museum objects analysed (Figure 9). 
Table 4 Changes in colour, tensile breaking load $(\mathrm{N})$, and extension (\%) of substitute textiles during accelerated ageing $\left(80^{\circ} \mathrm{C}, 58 \% \mathrm{RH}\right)$

\begin{tabular}{|c|c|c|c|c|c|c|c|}
\hline \multirow[t]{2}{*}{ Sample } & \multirow{2}{*}{$\begin{array}{l}\text { Extent of } \\
\text { ageing (weeks) }\end{array}$} & \multicolumn{4}{|c|}{ Difference in colour (aged versus unaged) } & \multicolumn{2}{|c|}{ Mean tensile properties } \\
\hline & & $\Delta \mathrm{E}_{00}{ }^{*}$ & $\Delta \mathrm{L}^{*}$ & $\Delta \mathrm{a}^{*}$ & $\Delta \mathbf{b}^{*}$ & Breaking load $(\mathrm{N})$ & Extension (\%) \\
\hline \multirow[t]{5}{*}{$\overline{W U}$} & 0 & 0.00 & 0.00 & 0.00 & 0.00 & $N D^{a}$ & ND \\
\hline & $\overline{1}$ & 1.14 & 0.05 & -0.40 & 1.38 & ND & ND \\
\hline & 2 & 1.33 & 0.32 & -0.48 & 1.58 & ND & ND \\
\hline & 3 & 1.75 & 0.17 & -0.61 & 2.16 & ND & ND \\
\hline & 4 & 2.44 & -0.22 & -0.72 & 3.17 & ND & ND \\
\hline \multirow[t]{5}{*}{$\overline{S U}$} & 0 & 0.00 & 0.00 & 0.00 & 0.00 & $70.2(4.9)^{b}$ & $28.2(1.7)^{b}$ \\
\hline & 1 & 1.04 & -0.06 & -0.32 & 1.00 & $64.2(4.4)$ & $25.2(0.8)$ \\
\hline & 2 & 1.57 & 0.00 & -0.44 & 1.54 & $65.5(4.8)$ & $24.9(2.5)$ \\
\hline & 3 & 2.16 & -0.48 & -0.54 & 2.17 & $62.3(4.7)$ & $24.8(2.7)$ \\
\hline & 4 & 2.59 & -0.40 & -0.57 & 2.70 & $61.6(4.3)$ & $21.7(2.1)$ \\
\hline \multirow[t]{5}{*}{$\mathrm{AU}$} & 0 & 0.00 & 0.00 & 0.00 & 0.00 & $239.9(43.1)$ & $3.9(0.5)$ \\
\hline & $\overline{1}$ & 2.39 & -2.17 & 0.67 & 2.78 & $255.5(38.1)$ & $3.7(0.5)$ \\
\hline & 2 & 3.08 & -2.82 & 1.05 & 3.43 & $262.8(47.3)$ & $3.8(0.5)$ \\
\hline & 3 & 3.03 & -1.63 & 1.39 & 4.22 & $250.0(40.3)$ & $3.9(0.6)$ \\
\hline & 4 & 3.95 & -2.64 & 1.76 & 5.29 & $248.8(28.9)$ & $3.5(0.5)$ \\
\hline \multirow[t]{5}{*}{ CU } & 0 & 0.00 & 0.00 & 0.00 & 0.00 & $117.1(9.2)$ & $9.1(0.8)$ \\
\hline & 1 & 0.62 & -0.15 & -0.10 & 0.61 & $101.9(15.7)$ & $8.2(1.0)$ \\
\hline & 2 & 1.20 & 0.06 & -0.06 & 1.26 & $107.2(11.6)$ & $8.2(0.7)$ \\
\hline & 3 & 1.52 & -0.84 & -0.07 & 1.48 & $107.1(8.3)$ & $8.6(0.5)$ \\
\hline & 4 & 1.82 & -0.28 & -0.06 & 1.92 & $108.2(11.0)$ & $8.1(0.5)$ \\
\hline \multirow[t]{5}{*}{$\overline{W p 1}$} & 0 & 0.00 & 0.00 & 0.00 & 0.00 & $\mathrm{ND}$ & ND \\
\hline & 1 & ND & ND & ND & ND & ND & ND \\
\hline & 2 & 2.74 & -0.50 & -0.39 & 2.73 & $\mathrm{ND}$ & ND \\
\hline & 3 & 3.64 & 0.42 & -0.46 & 3.70 & ND & ND \\
\hline & 4 & 5.70 & 3.33 & -0.62 & 5.21 & ND & ND \\
\hline \multirow[t]{5}{*}{ Sp1 } & 0 & 0.00 & 0.00 & 0.00 & 0.00 & $62.9(4.9)$ & $25.0(2.6)$ \\
\hline & 1 & 1.07 & -0.61 & -0.17 & 1.13 & $55.6(6.1)$ & $19.7(1.4)$ \\
\hline & 2 & 1.78 & -0.31 & -0.30 & 1.98 & $46.0(3.7)$ & $14.5(0.7)$ \\
\hline & 3 & 2.15 & 0.25 & -0.41 & 2.37 & $34.2(9.4)$ & $13.2(1.5)$ \\
\hline & 4 & 3.27 & 2.02 & -0.39 & 3.24 & $33.2(6.1)$ & $10.1(1.8)$ \\
\hline \multirow[t]{5}{*}{$\overline{A C 1}$} & 0 & 0.00 & 0.00 & 0.00 & 0.00 & $105.9(18.3)$ & $2.1(0.3)$ \\
\hline & 1 & 3.04 & 0.24 & 0.11 & 3.17 & $14.6(4.9)$ & $1.8(0.4)$ \\
\hline & 2 & 4.54 & -0.37 & 0.63 & 4.64 & $6.5(1.9)$ & $1.0(0.3)$ \\
\hline & 3 & 5.33 & -0.68 & 1.20 & 5.34 & $\mathrm{ND}^{\mathrm{C}}$ & $N^{c}$ \\
\hline & 4 & 4.96 & -2.00 & 1.08 & 4.75 & $\mathrm{ND}^{c}$ & $N D^{c}$ \\
\hline \multirow[t]{5}{*}{$\mathrm{Cc} 1$} & 0 & 0.00 & 0.00 & 0.00 & 0.00 & $68.3(5.3)$ & $6.9(0.7)$ \\
\hline & $\overline{1}$ & 7.35 & -4.23 & 0.30 & 6.92 & $29.5(3.9)$ & $4.9(0.6)$ \\
\hline & 2 & 10.49 & -4.68 & 1.29 & 10.55 & $13.0(0.4)$ & $3.7(0.6)$ \\
\hline & 3 & 12.15 & -5.71 & 2.29 & 12.24 & $7.7(1.1)$ & $3.5(0.2)$ \\
\hline & 4 & 13.24 & -6.72 & 3.02 & 13.22 & $6.2(0.7)$ & $3.5(0.2)$ \\
\hline
\end{tabular}

a. Not done.

b. Standard deviations of mean data are in parentheses.

c. Not done because the samples were too brittle to be prepared for analysis. 


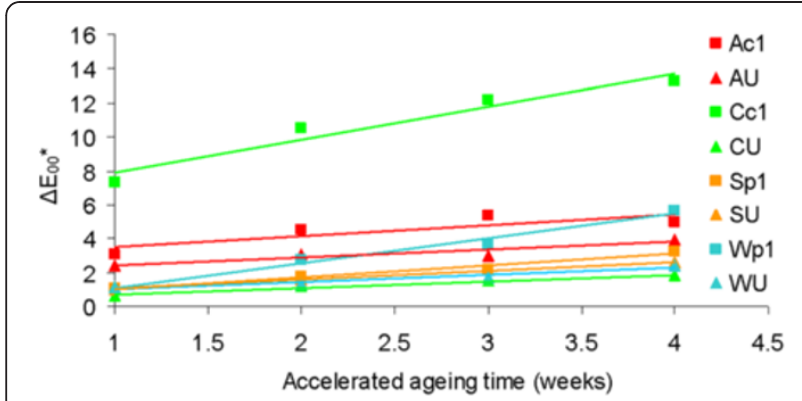

Figure 8 The effect of accelerated ageing on the colour difference $\left(\Delta \mathrm{E}_{00}{ }^{*}\right)$ of substitute textiles.

\section{Experimental}

\section{Dyeings}

The dyeings were performed on a Winch and a Jigger machine at the University of Manchester's dyehouse. Further information including material sources can be found in Additional file 2 .

\section{Accelerated ageing}

Substitute textiles were accelerated aged in two stacks (one for the dyed and one for the undyed samples) at $80^{\circ} \mathrm{C}$ and $58 \% \mathrm{RH}$ for $1,2,3$, and 4 weeks in a Sanyo Gallenkamp Environmental Chamber. These are similar to the conditions used in iron gall ink studies $\left(80^{\circ} \mathrm{C}, 65 \%\right.$ $\mathrm{RH}$ ) [37]. The stacks were arranged in the order of abaca, cotton, silk, and wool from the shelf upwards. The sample stacks were not rotated during ageing but were moved around on the shelf throughout ageing to counter any location-dependant variations in temperature and relative humidity in the chamber. See Additional file 3: Experimental section for more details.

\section{Analytical techniques}

Characterisation of the unaged substitute textiles and historic material was achieved using XRF, spectrophotometry, tensile testing, SEM-EDX, and surface $\mathrm{pH}$ testing. The aged substitute textiles were characterised using spectrophotometry and tensile testing. Brief methodologies for these techniques are described below. See Additional file 3: Experimental section for further details.

\section{$X R F$}

A Bruker ArtTax $\mu$-XRF spectrometer with a molybdenum X-ray tube and ArtTax4.9 software was used to analyse the unaged substitute textiles and the historic samples semi-quantitatively. Single thicknesses of substitute textiles were analysed in 8 locations on filter paper for $100 \mathrm{~s}$, using a $1.5 \mathrm{~mm}$ collimator, $50 \mathrm{kV}$, and $500 \mu \mathrm{A}$ in air. Analysis of material from museum objects occurred with and without helium purging over 100-400 s using a 0.65 $\mathrm{mm}$ or $1.5 \mathrm{~mm}$ collimator, $50 \mathrm{kV}$, and $500 \mu \mathrm{A}$.

Elemental peak areas were divided by the Compton peak area and multiplied by 1000 to give the XRF ratio values that are reported in Table 2. By normalising the elemental peak areas to the Compton peak area the XRF ratios acquired using different analytical methods are comparable.

\section{SEM-EDX}

Resin mounted cross-sections of dyed (p1 and $\mathrm{c} 1$ ) and undyed substitute textile fabrics were analysed using an Hitachi S-4800 Field Emission SEM and an Hitachi variable pressure S-3700 N SEM (operating at $30 \mathrm{~Pa}$ ). The SEMs were operated at $20 \mathrm{kV}$ and a $12 \mathrm{~mm}$ working distance for all analyses. Analysis was conducted using Oxford Instruments energy dispersive X-ray analysers with INCA software. EDX spectra were collected for

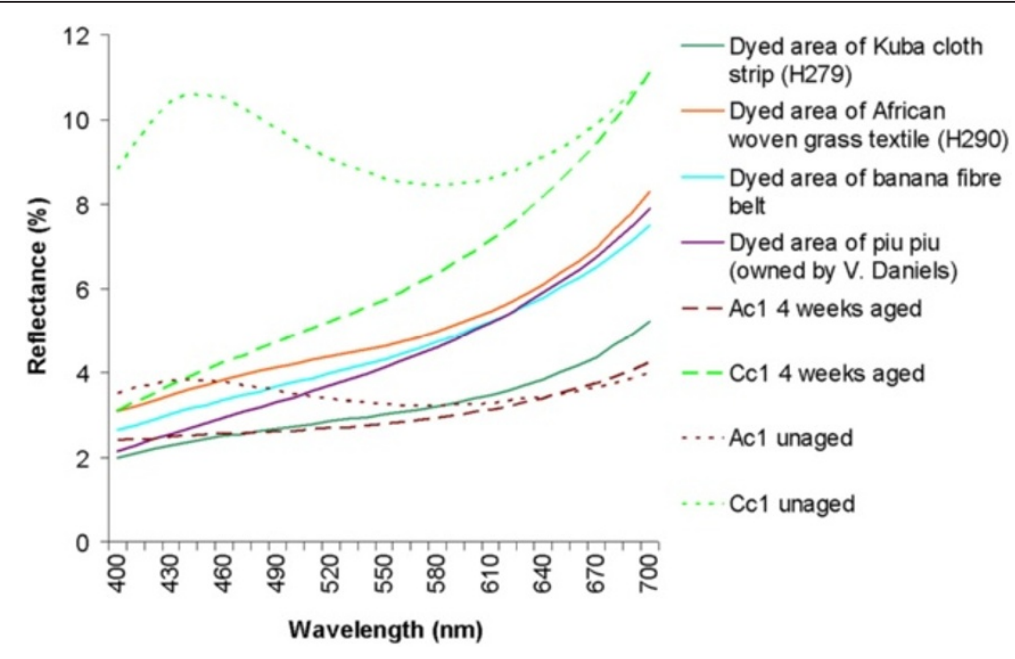

Figure 9 Visible reflectance spectra of cellulosic substitute textiles after 0 and 4 weeks of accelerated ageing $\left(80^{\circ} \mathrm{C}, 58 \% \mathrm{RH}\right)$ and of cellulosic museum objects. 
varying livetimes after optimisation of the iron peak versus total time taken for analysis: $200 \mathrm{~s}$ for abaca and silk; 200-300 s for cotton and 500-1000 s for wool. Dyed and undyed samples of the same material were analysed using the same conditions for comparison.

\section{Surface $\mathrm{pH}$ analysis}

Individual sheets of substitute textile were laid on a clean glass sheet and a drop of deionised water added. A Mettler Toledo InLab ${ }^{\circledR}$ Surface pH electrode attached to a Hanna Instruments $\mathrm{HI} 2210 \mathrm{pH}$ meter with temperature probe was then applied to the wetted area and held in place until the $\mathrm{pH}$ value stabilised. Ten analyses per substitute textile were made on randomly selected locations of randomly selected textile sheets. pH 4.01 and pH 7.01 buffer solutions were used to calibrate the equipment prior to analysis.

Samples of museum objects were analysed as above one and four times depending on sample size.

\section{Tensile testing}

$70-100 \mathrm{~mm}$ long strips of cotton and silk textiles (10 mm wide) and strips of abaca textiles (11 fibre bundles wide) were tested using an Instron 4411 tensile tester with $500 \mathrm{~N}$ static load cell and Series IX software. The warp direction of the cotton, abaca and silk fabrics was tested. The strips had been conditioned to approximately $21^{\circ} \mathrm{C}$ and $50 \% \mathrm{RH}$ overnight before testing. Between eight and ten strips were analysed per sample (as sample size allowed) using a $50 \mathrm{~mm}$ gauge length and $10 \mathrm{~mm} \mathrm{~min}{ }^{-1}$ extension speed as used by Garside, Wyeth and Zhang [38]. Exponential trend lines were fitted to tensile testing data using MS Excel.

\section{Colour measurement}

Average $\mathrm{L}^{*}, \mathrm{a}^{*}, \mathrm{~b}^{*}$ values of $\mathrm{SCI} / 100$ and SCE/100 data were collected using a Konica/Minolta CM-2600d spectrophotometer, Spectramagic 3.60 software and the following settings: $\mathrm{SCI}+\mathrm{SCE}$, medium aperture, UV included, $10^{\circ}$ observer and D65 illuminant. The spectrophotometer was calibrated using a white standard before analysis and the textiles were analysed on black velvet.

10 randomly selected sheets of each unaged substitute textile were analysed in 3 randomly selected locations while each aged substitute textile sample was analysed in 5 randomly selected locations. Single layers of textile were analysed except for the unaged abaca textiles which were folded so that two layers were measured simultaneously due to the looseness of the weave compared to the other textiles. Aged abaca was too brittle to be folded without breaking and so one layer of aged abaca was measured at a time.

CIE2000 was used to calculate the $\Delta \mathrm{E}_{00}{ }^{*}, \Delta \mathrm{L}^{*}, \Delta \mathrm{a}^{*}$, $\Delta \mathrm{b}^{*}$ from SCE/100 data from the aged textile compared to the unaged equivalent textile.
The small aperture rather than medium aperture was used to analyse up to three areas of the historic samples as sample size allowed. All other conditions were the same as for spectrophotometry of substitute textiles.

\section{Conclusions}

Cotton, abaca, wool, and silk iron-tannate dyed substitute fabrics have been produced on a large and unprecedented scale for use in stabilisation treatment studies. The achieved colours were characteristic of iron-tannate complexes. The harsh dyeing conditions led to immediate deterioration of mechanical properties of the textiles. Dyeing introduced significant acid and metal ion content to the textiles which was shown to be present in the structurally important internal areas of the dyed cotton, abaca, and silk fibres. The use of a higher temperature during dyeing would have improved dye diffusion into the internal areas of the wool fibres. Colour, surface $\mathrm{pH}$, and metal ion content were found to be suitably uniform across the textiles for the needs of this accelerated ageing study and future stabilisation treatment studies.

The dyed cotton, abaca, and silk substitute textiles lost tensile strength and extensibility significantly faster than undyed equivalents on accelerated thermal ageing, as has been known for hundreds of years to occur to irontannate dyed objects. Discolouration of the dyed textiles was also observed during accelerated ageing due to the breakdown of the iron-tannate dye complex resulting in colours of cellulosic textiles being comparable to the colours of naturally aged cellulosic museum objects. Consequently, the cotton, abaca, and silk model textiles were found to be valid substitutes for historic iron-tannate dyed textiles in stabilisation treatment studies.

\section{Additional files}

Additional file 1: Iron-tannate dye chemistry. Text and schemes [2-7,9,10,39-61].

Additional file 2: Further substitute textile development and dyeing method details. Text and images [62-66].

Additional file 3: Experimental section. Text only [37,38,67].

\section{Abbreviations}

SEM-EDX: Scanning Electron Microscopy-Energy Dispersive X-ray Microanalysis; XRF: X-ray Fluorescence; C: Cotton; A: Abaca (Musa textilis); W: Wool; S: Silk; p1-3: Dye formulations 1-3 described in Table 1 for proteinaceous textiles; c1-3: Dye formulations 1-3 described in Table 1 for cellulosic textiles; U: Undyed model textile; CIE2000: Commission Internationale de L'Eclairage 2000 colour space formula.

\section{Competing interests}

The authors declare that they have no competing interests.

\section{Authors' contributions}

$\mathrm{MH}$ and $\mathrm{CC}$ proposed the project. HW developed the dye formulations used on the model textiles and with assistance from Phil Cohen from the University of Manchester, produced the dyed model textiles in the dyehouse at the University of Manchester. HW performed all the analyses and data 
interpretation presented. Supervision was provided when required by CC and $\mathrm{MH}$. All authors read and approved the final manuscript.

\section{Acknowledgements}

We thank AHRC, EPSRC, and the Science and Heritage Programme for their financial and other support given to this project. We also thank Dr Vincent Daniels, Dr Muriel Rigout, and Pippa Cruickshank for their assistance in this project, Phil Cohen for assisting in the production of the model textiles, Adrian Handley for assisting in the tensile testing, Nigel Meeks for assisting with SEM-EDX, Dr Huw Owens for assisting with spectrophotometry data, Dr David Peggie for the use of and assistance with the environmental chamber at the National Gallery, and Louise Bacon from the Horniman Museum for the deteriorated Maori samples.

\section{Received: 8 November 2011 Accepted: 4 April 2012}

\section{Published: 22 May 2012}

\section{References}

1. Khanbabaee K, van Ree T: Tannins: classification and definition. Nat Prod Rep 2001, 18:641-649.

2. Krekel C: The chemistry of historical iron gall inks. Int J Forensic Doc Exam 1999, 5:54-58.

3. More N, Smith G, Te Kanawa R, Miller I: Iron-sensitised degradation of black-dyed Maori textiles. In Dyes in History and Archaeology 19, the Royal Museum, National Museums of Scotland, Edinburgh, 19-20 October 2003. Edited by Kirby J. Edinburgh: Archetype Publications; 2003:144-148. ISBN 1-873132-14-X.

4. Daniels VD: Degradation of Artefacts caused by Iron-Containing Dyes. In Dyes in History and Archaeology 16/17, Lyons, 11-12 December 1997 and Greenwich, 26-27 November 1998 (Kirby J ed. pp. 211-215. Lyon and Greenwich: Archetype Publications Ltd 2002; 1998:211-215. ISBN: 1-873132-97-2.

5. O'Connor D, Richards A: The Right Mud: Studies in Mud-Tannic Dyeing in West China and West Surrey. In Dyes in History and Archaeology 18, the Royal Institute For Cultural Heritage, Brussels,21-22 October 1999. Edited by Jo K. Brussels: Archetype Publications Ltd; 2002:41-46. ISBN 1-873132-33-6.

6. Sistach MC, Gibert JM, Areal R: Ageing of laboratory irongall inks studied by reflectance spectrometry. Restaurator 1999, 20:151-166.

7. Neevel JG: The development of in-situ methods for identification of iron gall inks. In Iron Gall Inks: On Manufacture, Characterisation, Degradation and Stabilisation. Edited by Strlic M, Kolar J. Ljubljana: National and University Library; 2006:147-172.

8. Kolar J, Strlic M (Eds): Iron Gall Inks: On Manufacture, Characterisation, Degradation and Stabilisation. Ljubljana: National and University Library; 2006.

9. Neevel JG: Phytate: a potential conservation agent for the treatment of ink corrosion caused by irongall inks. Restaurator 1995, 16:143-160.

10. Daniels V: Factors affecting the deterioration of the cellulosic fibres in blackdyed New Zealand Flax ( Phormium Tenax ). Stud Conserv 1999, 44:73-85.

11. Te Kanawa R, Smith GJ, Fenton GA, Miller IJ, Dunford CL: Evaluation of Consolidants for Black Iron-Tannate-Dyed Maori Textiles. In Dyes in History and Archaeology: 21 Avignon and Lauris, France 2002. Edited by Kirby J. Avignon and Lauris: Archetype Publications Ltd; 2008:224-229. ISSN: 0959-0641.

12. Sato M, Okubayashi S: Consolidation treatment of Japanese ceremonial doll's hair at Edo Period with polyethylene glycol. J Text Eng 2010, 56:65-70.

13. Sandy $M, B a c o n ~ L: A$ tensile testing method for monocotyledon leaves with parallel venation. In ICOM Committee for Conservation, ICOM-CC, 15th Triennial Conference New Delhi, 22-26 September 2008. New Delhi: Allied Publishers Pvt Ltd; 2008:198-205. ISBN 9788184243444.

14. Simpson WS: Wool Chemistry. In Wool: Science and Technology. Edited by Simpson WS, Crawshaw GH. Cambridge: Woodhead Publishing Limited in association with The Textile Institute; 2002:130-159.

15. Hearle JWS, Peters RH: Fibre Structure. Manchester. London: The Textile Institute: Butterworths; 1963.

16. Christie RM: Colour Chemistry. Cambridge: The Royal Society of Chemistry; 2001.

17. Frazier RA, Deaville ER, Green RJ, Stringano E, Willoughby I, Plant J, Mueller-Harvey I: Interactions of tea tannins and condensed tannins with proteins. J Pharm Biomed Anal 2010, 51:490-495.

18. Bhattacharya SD, Shah AK: Metal ion effect on dyeing of wool fabric with catechu. J Soc Dyers Colourists 2000, 116:10-12.

19. Fukatsu K, Isa M: Interaction of wool keratin fibers and copper(II) ions. Text Res J 1986, 56:774-775.
20. Maclaren JA, Milligan B: Wool Science - The chemical reactivity of the wool fibre. Marrickville: Science Press; 1981.

21. Letelier ME, Sanchez-Jofre S, Peredo-Silva L, Cortes-Troncoso J, AracenaParks P: Mechanisms underlying iron and copper ions toxicity in biological systems: Pro-oxidant activity and protein-binding effects. Chem Biol Interact 2010, 188:220-227.

22. Letelier ME, Lepe AM, Faundez M, Salazar J, Marin R, Aracena P, Speisky $\mathrm{H}$ : Possible mechanisms underlying copper-induced damage in biological membranes leading to cellular toxicity. Chem Biol Interact 2005, 151:71-82.

23. Chen WX, Lu SF, Yao YY, Pan Y, Shen ZQ: Copper(II)-Silk Fibroin Complex Fibers as Air-Purifying Materials for Removing Ammonia. Text Res J 2005, 75:326-330.

24. Timar-Balazsy A, Eastop D: Chemical principles of textile conservation. Oxford: Butterworth-Heinemann; 1998.

25. Hartley FR: The uptake of aluminium by wool. Aust J Chem 1968, 21:1013-1022.

26. Hartley FR: Studies in chrome mordanting. II. The binding of chromium(III) cations to wool. Aust J Chem 1968, 21:2723-2735.

27. Bird CL: The theory and practice of wool dyeing. 4th edition. Bradford: The Society of Dyers and Colourists; 1972.

28. Guthrie RE, Laurie SH: The binding of copper(II) to mohair keratin. Aust J Chem 1968, 21:2437-2443.

29. Hsieh Y-L: Chemical structure and properties of cotton. In Cotton: Science and Technology. Edited by Gordon S, Hsieh Y-L. Boston and Cambridge: CRC Press and Woodhead Publishing Limited; 2007:3-34.

30. Sun R, Fang JM, Goodwin A, Lawther JM, Bolton AJ: Fractionation and characterization of polysaccharides from abaca fibre. Carbohydr Polym 1998, 37:351-359.

31. Luo MR, Cui G, Rigg B: The development of the CIE 2000 colour-difference formula: CIEDE2000. Color Res App/ 2001, 26:340-350.

32. Te Kanawa R, Thomsen S, Smith G, Miller I, Andary C, Cardon D: Traditional Maori Dyes. In Dyes in History and Archaeology 18, the Royal Institute for Cultural Heritage, Brussels, 21-22 October 1999. Edited by Kirby J. Brussels: Archetype Publications; 2002:47-50.

33. Pullan $M$, Baldwin A: The evolution of a treatment strategy for an Akali Sikh turban. In ICOM Committee for Conservation, ICOM-CC, 15th Triennial Conference, 22-26 September 2008. Edited by Bridgland J. Delhi: Allied Publishers Pvt; 2008:191-197. ISBN 9788184243444.

34. HofenkdeGraaff $\mathrm{JH}$ : Dyeing and Writing: A comparison of the use and degradation of iron-gall complexes on textiles and paper. In Contributions to Conservation - Research in Conservation at the Netherlands Institute for Cultural Heritage (ICN). Edited by Mosk JA, Tennent NH. London: James \& James (Science Publishers) Ltd; 2002:34-41. ISBN 1-902916-09-3.

35. Broadbent AD: Basic Principles of Textile Coloration. Bradford: Society of Dyers and Colourists; 2001.

36. Kolar J, Strlic M, Pihlar B: Methodology and analytical techniques in studies of iron gall ink and its corrosion. In Iron Gall Inks: On Manufacture, Characterisation, Degradation and Stabilisation. Edited by Kolar J, Strlic M. Ljubljana: National and University Library; 2006:95-118.

37. Kolar J, Mozir A, Balazic A, Strlic M, Ceres G, Conte V, Mirruzzo V, Steemers T, De Bruin G: New antioxidants for treatment of transition metal containing inks and pigments. Restaurator 2008, 2008:184-198.

38. Garside $P$, Wyeth $P$, Zhang $X$ : Understanding the ageing behaviour of nineteenth and twentieth century tin-weighted silks. J Inst Conserv 2010, 33:179-193.

39. Wunderlich $\mathrm{CH}$ : Über Eisengallustinte. Zeitung der Anorganischen Algemeinen Chemie 1991, 598-599:371-376.

40. Wunderlich $\mathrm{CH}$ : Geschichte und Chemie der Eisengallustinte - Rezepte, Reaktionen und Schadwirkungen. Restauro 1994, 100:414-421.

41. Tasneem Z, Kazmi SA, Sultana K: Role of water in aqueous solution of iron gallic acid complexes. Pak J Sci Ind Res 1991, 34:45-48.

42. Marmolle F, Leize E, Mila I, Van Dorsselaer A, Scalbert A, Albrecht-Gary AM: Polyphenol metallic complexes: characterization by electrospray mass spectrometric and spectrophotometric methods. Analusis Magazine 1997, 25:53-55.

43. Hynes MJ, O'Coinceanainn M: The kinetics and mechanisms of the reaction of iron(III) with gallic acid, gallic acid methyl ester and catechin. J Inorg Biochem 2001, 85:131-142.

44. Sungur S, Uzar A: Investigation of complexes tannic acid and myricetin with Fe(III). Spectrochim Acta A 2008, 69:225-229. 
45. Jaen JA, Gonzalez L, Vargas A, Olave G: Gallic Acid, Ellagic Acid and Pyrogallol Reaction with Metallic Iron. Hyperfine Interactions 2003, 148/149:227-235.

46. Delamare F, Repoux M: Studying dyes by Time of Flight Secondary lon Mass Spectrometry. In Dyes in History and Archaeology 20; Amsterdam. Edited by Kirby J.: Archetype Publications; 2001.

47. Darbour M: Les encres métallogalliques. Université de Paris VI: Étude de la dégradation de l'acide gallique et analyse du complexe ferrogallique; 1980

48. Iglesias J, Garcia de Saldana E, Jaen JA: On the Tannic Acid Interaction with Metallic Iron. Hyperfine Interactions 2001, 134:109-114.

49. Kipton H, Powell J, Taylor MC: Interactions of Iron(II) and Iron(III) with Gallic Acid and its Homologues: a Potentiometric and Spectrophotometric Study. Aust I Chem 1982, 35:739-756.

50. Darbour M, Bonnassies S, Flieder F: Les encres métallogalliques. Étude de la dégradation de l'acide gallique et analyse du complexe ferrogallique. In ICOM-CC 6th Triennial Meeting. Los Angeles, USA: ICOM-CC; 1981:1-14.

51. Wagner B, Bulska E, Stahl B, Heck M, Ortner HM: Analysis of Fe valence states in iron-gall inks from XVIth century manuscripts by $57 \mathrm{Fe}$ Mössbauer spectroscopy. Anal Chim Acta 2004, 527:195-202.

52. Daniels VD: The Chemistry of Iron Gall Ink. In The Iron Gall Ink Meeting - First triennial conservation conference (Brown AJE ed. pp. 31-36. Newcastle upon Tyne: Conservation of Fine Art, University of Northumbria; 2000:31-36.

53. Slawinska D, Slawinski J, Polewski K, Pukacki W: Chemiluminescence in the peroxidation of tannic acid. Photochemistry and Photobiology 1979, 30:71-80.

54. Sistach MC, Espedaler I: Organic and inorganic components of iron gall inks. In Preprints of the ICOM Committee for Conservation10th Triennial Meeting, Washington DC. Washington D.C: ICOM Committee for Conservation; 1993:485-490.

55. Shahani CJ, Hengemihle FH: The influence of copper and iron on the permanence of paper. In Historic textiles and paper materials - Conservation and characterization. Edited by Needles H, L., Zeronian SH. Washington, DC American Chemical Society; 1986: 387-410. [Comstock MJ (Series Editor): Advances in Chemistry Series].

56. Neevel JG: (Im)possibilities of the phytate treatment of ink corrosion. In Contributions to Conservation. Edited by Mosk JA, Tennent NH.: James \& James; 2002:74-86.

57. McDonald M, Mila I, Scalbert A: Precipitation of metal ions by plant polyphenols: Optimal conditions and origin of precipitation. J Agric Food Chem 1996, 44:599-606.

58. Kolar J, Stolfa A, Strlic M, Pompe M, Pihlar B, Budnar M, Simcic J, Reissland B: Historical iron gall ink containing documents - Properties affecting their condition. Anal Chim Acta 2006, 555:167-174.

59. IUPAC: Compendium of Chemical Terminology. Oxford: Blackwell Scientific Publications; 1997.

60. Selih VS, Strlic M, Kolar J, Pihlar B: The role of transition metals in oxidative degradation of cellulose. Polym Degradation Stability 2007, 92:1476-1481.

61. Budnar M, Simcic J, Ursic M, Rupnik Z, Pelicon P: Transition metals in historical documents, determined by In-Air PIXE. In Iron Gall Inks: On Manufacture, Characterisation, Degradation and Stabilisation. Edited by Strlic M, Kolar J. Ljubljana: National and University Library; 2006:141-146.

62. Rosetti G: The Plictho of Gioanventura Rosetti; Instructions in the Art of the Dyers which Teaches the Dyeing of Woolen Cloths, Linens, Cottons, and Silk by the Great Art as Well as by the Common. Translation of the First Edition of 1548 by Sidney M. Edelstein and Hector C. Borghetty. Cambridge, Massachusetts: MIT Press; 1548.

63. Anonymous: Black Silks. Textile Colorist 1898, 20:287-288.

64. Bird FJ: The Dyer's Hand-book. Manchester: John Heywood; 1876.

65. Haigh J: The Dyer's Assistant in the Art of Dying Wool and Woollen Goods. London: 1800

66. Packer T: The Dyer's Guide. 2nd., corrected and materially improved edn. London: Printed for Sherwood, Gilbert, and Piper; 1830

67. Porck HJ: Rate of Paper Degradation - The Predictive Value of Artificial Aging Tests. Amsterdam: European Commission on Preservation and Access; 2000

\section{doi:10.1186/1752-153X-6-44}

Cite this article as: Wilson et al:: Production and validation of model iron-tannate dyed textiles for use as historic textile substitutes in stabilisation treatment studies. Chemistry Central Journal 2012 6:44.

\section{Publish with ChemistryCentral and every scientist can read your work free of charge \\ "Open access provides opportunities to our colleagues in other parts of the globe, by allowing anyone to view the content free of charge." W. Jeffery Hurst, The Hershey Company. \\ - available free of charge to the entire scientific community \\ - peer reviewed and published immediately upon acceptance \\ - cited in PubMed and archived on PubMed Central \\ - yours - you keep the copyright \\ Submit your manuscript here: \\ http://www.chemistrycentral.com/manuscript/<smiles>c1ccccc1</smiles> \\ Chemistry Central}

